\title{
Bacteriophage-Encoded DNA Polymerases-Beyond the Traditional View of Polymerase Activities
}

\author{
Joanna Morcinek-Orłowska ${ }^{1,+}{ }^{,}$Karolina Zdrojewska ${ }^{1,+}+$ (D) and Alicja Węgrzyn ${ }^{2, *(\mathbb{D})}$ \\ 1 Department of Molecular Biology, Faculty of Biology, University of Gdansk, Wita Stwosza 59, \\ 80-308 Gdansk, Poland; joanna.morcinek-orlowska@phdstud.ug.edu.pl (J.M.-O.); \\ karolina.zdrojewska@phdstud.ug.edu.pl (K.Z.) \\ 2 Laboratory of Phage Therapy, Institute of Biochemistry and Biophysics, Polish Academy of Sciences, \\ Kładki 24, 80-822 Gdansk, Poland \\ * Correspondence: alicja.wegrzyn@biol.ug.edu.pl; Tel.: +48-58-523-6040 \\ + These authors contributed equally to this work.
}

check for updates

Citation: Morcinek-Orłowska, J.; Zdrojewska, K.; Wẹgrzyn, A. Bacteriophage-Encoded DNA Polymerases-Beyond the Traditional View of Polymerase Activities. Int. J. Mol. Sci. 2022, 23, 635. https://doi.org/10.3390/ ijms23020635

Academic Editor: Antonio Mas López

Received: 30 November 2021

Accepted: 6 January 2022

Published: 7 January 2022

Publisher's Note: MDPI stays neutral with regard to jurisdictional claims in published maps and institutional affiliations.

Copyright: (C) 2022 by the authors. Licensee MDPI, Basel, Switzerland. This article is an open access article distributed under the terms and conditions of the Creative Commons Attribution (CC BY) license (https:// creativecommons.org/licenses/by/ $4.0 /)$.

\begin{abstract}
DNA polymerases are enzymes capable of synthesizing DNA. They are involved in replication of genomes of all cellular organisms as well as in processes of DNA repair and genetic recombination. However, DNA polymerases can also be encoded by viruses, including bacteriophages, and such enzymes are involved in viral DNA replication. DNA synthesizing enzymes are grouped in several families according to their structures and functions. Nevertheless, there are examples of bacteriophage-encoded DNA polymerases which are significantly different from other known enzymes capable of catalyzing synthesis of DNA. These differences are both structural and functional, indicating a huge biodiversity of bacteriophages and specific properties of their enzymes which had to evolve under certain conditions, selecting unusual properties of the enzymes which are nonetheless crucial for survival of these viruses, propagating as special kinds of obligatory parasites. In this review, we present a brief overview on DNA polymerases, and then we discuss unusual properties of different bacteriophage-encoded enzymes, such as those able to initiate DNA synthesis using the protein-priming mechanisms or even start this process without any primer, as well as able to incorporate untypical nucleotides. Apart from being extremely interesting examples of biochemical biodiversity, bacteriophage-encoded DNA polymerases can also be useful tools in genetic engineering and biotechnology.
\end{abstract}

Keywords: bacteriophage; DNA polymerases; DNA replication

\section{Introduction}

In 1953, Watson and Crick resolved the structure of double-stranded DNA. This discovery enabled a huge development in molecular biology. Subsequent work on understanding the cellular mechanisms of DNA replication revealed that this process is tightly regulated and requires the joint action of several protein factors that interact with themselves and with DNA. The key enzyme in DNA replication is DNA polymerase, responsible for the processivity and fidelity of DNA synthesis [1,2].

Mechanistically, five main steps can be distinguished when describing DNA synthesis by polymerase. The first is the physical formation of hydrogen bonds between the relevant bases: two bonds between adenine and thymine or three bonds between cytosine and guanine. Subsequently, water is removed from the active site of the polymerase. As a result, the nucleotide can be attached by changing the conformation of the enzyme in the active site. This results in the formation of a phosphodiester bond between the last base of the primer and the new nucleotide. The free $3^{\prime}-\mathrm{OH}$ end is required for this $[3,4]$.

Polymerases are common across all taxa since every organism needs to replicate its genetic material. There is no exception with viruses-after infecting the host cell they have to rapidly copy their genome and produce progeny particles. Because the genome of 
different viral taxa can be either DNA or RNA of different types (linear, circular, single-or double-stranded), viruses rely on different polymerases to meet their replication needs. Logically, DNA-dependent DNA polymerases are used to replicate the genome of DNA viruses [5].

A specific kind of virus is the bacteriophage, which infects bacteria. The ability to produce phage progeny particles often depends on proteins encoded by host genes, including host DNA polymerase. However, there are some bacteriophages that encode their own polymerases. Among the best known DNA polymerase-encoding viruses, there are $\phi 29$, T7, T4 and T4-like RB69 phages [6-9], but other bacteriophages coding for their own DNA polymerases are being constantly discovered.

Due to their prevalence across the wide variety of environmental conditions, bacteriophages are a source of exploration for yet undiscovered DNA polymerases. They may have unusual properties that exceed far beyond the traditional notion of DNA polymerase, that is an enzyme of specific structure with obligatory $5^{\prime}$ to $3^{\prime}$ DNA synthesis activity and optional exonuclease activity [2,5]. In this review we highlight the basic information about 'typical' DNA polymerases of the best-known bacteriophages and show the recent examples of phage-encoded polymerases with noncanonical activities or specific, previously undescribed features.

\section{DNA Polymerases}

DNA polymerases have a structure resembling the right hand. They have three main domains: palm, fingers, and thumb. The fingers domain interacts with incoming ssDNA and dNTPs, and the thumb domain binds dsDNA. The palm domain contains an active site where amino acid residues bind divalent ions, allowing primer elongation on the DNA template [10].

Despite their structural similarities, DNA polymerases, based on phylogenetic analysis and nucleotide sequence similarity, were divided into seven families: A, B, C, D, X, Y and RT (Table 1) [11]. The DNA polymerases of family A have replicative and repair activities. With the $3^{\prime} \rightarrow 5^{\prime}$ exonuclease activity, proofreading is provided, allowing the repair of a mispaired nucleotide, while the $5^{\prime} \rightarrow 3^{\prime}$ exonuclease activity allows the removal of RNA primers. Polymerases of this family are found in eukaryotic organisms ( $\mathrm{Pol} \gamma, \mathrm{Pol} \theta, \mathrm{Pol} v)$, bacteria (Pol I) and viruses (T7 DNA pol) $[4,12,13]$.

Family B polymerases, unlike family A enzymes, lack $5^{\prime} \rightarrow 3^{\prime}$ exonucleolytic activity. In the case of polymerases found in eukaryotic cells, most of them also lack the domain responsible for $3^{\prime} \rightarrow 5^{\prime}$ exonuclease activity. However, in other taxa, $3^{\prime} \rightarrow 5^{\prime}$ exonuclease has a 1000-fold higher activity than the Klenow fragment of the Escherichia coli Pol I. B family polymerases are found in eukaryota (Pol $\zeta, \alpha, \sigma)$, bacteria (Pol II), archea (DNA pol B) and viruses (T4 DNA pol) [4,6,12-15].

The $C$ polymerase family comprises enzymes that are the main proteins responsible for chromosomal replication. They do not show much similarity to the polymerases of the A and B families. They are holoenzymes whose activity depends on interactions with at least 10 other proteins. These enzymes are found in bacteria, and an example of such a polymerase is Pol III $[12,13,16]$.

The D family enzymes are characterized by the presence of two subunits: the small DP1 (responsible for $3^{\prime} \rightarrow 5^{\prime}$ exonuclease activity) and the large DP2, which has a polymerase activity. To date, they have only been discovered in euryarchaeota, and an example is Pol D [13].

Polymerases included in the $\mathrm{X}$ family are small and monomeric. They catalyze replication, are involved in recombination and DNA repair, and have DNA repair capabilities that are mainly based on gap filling and joining broken DNA strands. These enzymes can be found in many taxa: eukaryota ( $\mathrm{Pol} \beta, \sigma, \lambda, \mu)$, bacteria ( $\mathrm{Pol} \mathrm{X})$, archea (Pol X), and viruses (African Swine Fever Virus DNA pol) $[4,13,17]$. 
Table 1. Families of DNA polymerases.

\begin{tabular}{|c|c|c|c|}
\hline $\begin{array}{c}\text { DNA Polymerase } \\
\text { Family }\end{array}$ & Taxa & Example(s) & Main Function(s) \\
\hline $\mathrm{A}$ & $\begin{array}{c}\text { Eukaryota } \\
\text { Bacteria } \\
\text { Viruses }\end{array}$ & $\begin{array}{c}\text { Pol } \gamma, \text { Pol } \theta, \text { Pol v } \\
\text { Pol I } \\
\text { T7 DNA pol }\end{array}$ & Replication, repair \\
\hline B & $\begin{array}{c}\text { Eukaryota } \\
\text { Bacteria } \\
\text { Archea } \\
\text { Viruses }\end{array}$ & $\begin{array}{c}\text { Pol } \zeta, \alpha, \sigma \\
\text { Pol II } \\
\text { DNA pol B } \\
\text { T4 DNA pol }\end{array}$ & Replication, repair \\
\hline $\mathrm{C}$ & Bacteria & Pol III & Replication \\
\hline $\mathrm{D}$ & Archea & Pol D & Replication \\
\hline$x$ & $\begin{array}{c}\text { Eukaryota } \\
\text { Bacteria } \\
\text { Archea } \\
\text { Viruses }\end{array}$ & $\begin{array}{c}\text { Pol } \beta, \sigma, \lambda, \mu \\
\text { Pol X } \\
\text { Pol X } \\
\text { ASFV DNA pol }\end{array}$ & Repair \\
\hline $\mathrm{Y}$ & $\begin{array}{c}\text { Eukaryota } \\
\text { Bacteria } \\
\text { Archea }\end{array}$ & $\begin{array}{c}\text { Pol } \iota, \kappa, \eta \\
\text { Pol IV i V } \\
\text { Dpo4 DNA pol }\end{array}$ & Translesion synthesis \\
\hline RT & $\begin{array}{l}\text { Eukaryota } \\
\text { Viruses }\end{array}$ & $\begin{array}{c}\text { Telomerase } \\
\text { Pol HBV virus }\end{array}$ & $\begin{array}{l}\text { RNA-dependent } \\
\text { DNA synthesis }\end{array}$ \\
\hline
\end{tabular}

In the $Y$ family, polymerases have an additional little finger domain that allows them to bypass strand breaks. As a result, even damaged DNA can be replicated. Examples of such enzymes are the polymerases found in eukaryota (Pol $\iota, k, \eta)$, bacteria (Pol IV and V) and archea (Dpo4 DNA pol) $[4,13,18,19]$.

There are also DNA polymerases that are RNA-dependent. They enable the synthesis of DNA strands on the ssRNA template. They belong to the RT family. The process of reverse transcription is also used by telomerase in the elongation of telomeres in eukaryotic cells. Another example is the polymerase encoded by the HBV virus [13].

\section{Phage DNA Polymerases in Action-DNA Replication of the Well-Studied Bacteriophages}

DNA polymerases of $\phi 29$ and T4 bacteriophages belong to the B family, whereas phage T7 DNA polymerase is a member of the A family $[9,20,21]$. The replication mechanisms of three above phages differ from each other [6-8] and are briefly depicted in the following section.

\subsection{DNA Replication of $\phi 29$ Phage}

DNA polymerases require a free hydroxyl group at the $3^{\prime}$-end to catalyze DNA replication. Typically, it is provided by the activity of a primase, which synthesizes a short stretch of RNA on template DNA. However, the initiation of replication of bacteriophage $\$ 29$ does not require the presence of RNA polymerase. The bacteriophage $\$ 29$ has a genome in the form of double-stranded linear DNA. During infection, once the genetic material enters the host cell, the initiation of replication takes place through the $\mathrm{p} 3$ terminal protein covalently linked to the $5^{\prime}$-end of the DNA. Then the DNA ends are destabilized due to the interaction with the p6 protein [22-24]. It also turned out that the last and penultimate nucleotides in the genome of bacteriophage $\phi 29$ are TT (Figure 1A).

It was noted that the first nucleotide added is dAMP, which becomes attached to the penultimate nucleotide of the template $[25,26]$. It takes place with the participation of several proteins. P6 lowers the $\mathrm{K}_{\mathrm{M}}$ dAMP value, thanks to which $\mathrm{p} 2$ catalyzes the deoxyadenylation of Ser232 in the $\mathrm{p} 3$ protein $[23,26]$. Commencement of replication at the +2 site could result in the loss of more nucleotides during subsequent replication cycles. As such phenomenon was not observed in phage $\$ 29$, it was proved that a sliding-back 
mechanism exists. It allows the dAMP-p3-p2 complex to move back to the +1 position, without shifting the template, which causes the reattachment of another nucleotide at the +2 position [26]. If the newly synthesized strand reaches a size of at least six nucleotides, DNA polymerase detaches from the p3 protein and continues replication independently. The resulting ssDNA is covered by p5 SSB [8] (Figure 1B).

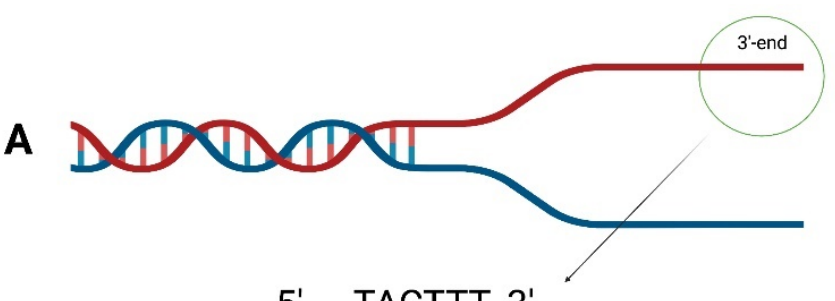

\section{$5^{\prime}-\ldots$ TACTTT- 3}

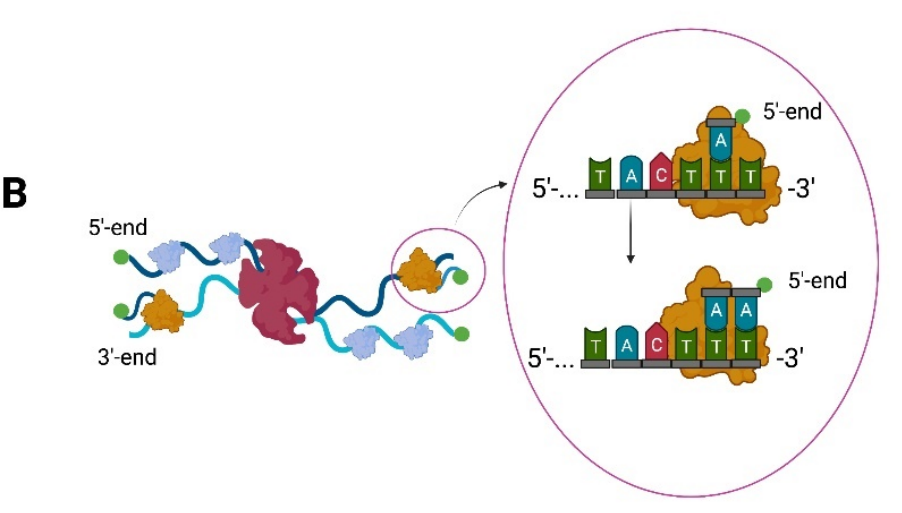

Figure 1. Replication of the bacteriophage $\phi 29$ genome. (A) The 3 -terminal region of bacteriophage $\$ 29$ genome. (B) The p6 protein (red) destabilizes the ends of the DNA, making replication possible. The initiation of replication of bacteriophage $\$ 29$ occurs through the terminal protein p3 (green) which is covalently bound to the $5^{\prime}$ end. DNA polymerase (orange) in complex with p3 protein and dAMP pairs the first nucleotide with the penultimate $\mathrm{T}$ from the template. A sliding-back mechanism then occurs, which results in the entire complex moving to the +1 position of the newly synthesized strand, allowing re-matching at the penultimate template site. The ssDNA is covered by p5 SSB (blue). Schemes follow the same formatting.

\subsection{DNA Replication of T4 Phage}

The genetic material of the T4 bacteriophage is a linear dsDNA. Its replication process, as compared to the rest of those described in this paper, is more complicated. This is related to the interaction with more proteins required to carry out the process. For replication to occur, proteins encoded by phage DNA genes are required. Therefore, it is transcription that comes first. Once all the proteins are present, the first round of replication is initiated at one of several ori sites (oriA, oriC, oriE, oriF, or oriG). Depending on the place where replication initiation takes place, phage encoded transcriptional activators are required MotA for oriA, oriF, oriG, and DbpC for oriE [27]. Origins of replication sites are recognized by host RNA polymerase after replacement of the $\sigma^{70}$ subunit with bacteriophage-encoded AsiA $\sigma$-factor. This results in the formation of the $\mathrm{R}$ loop structure on the $3^{\prime}$ to $5^{\prime}$ strand which serves as a primer for unidirectional leading-strand synthesis [28] (Figure 2A). The clamp loader gp44/gp62 complex then loads the sliding clamp gp45 at the end of the resulting heteroduplex, thereby allowing the attachment of bacteriophage gp43 DNA polymerase. The unfolding of the double-stranded construct is ensured by the gp41 helicase, which is brought to the replisome by the gp59 protein [29-31] (Figure 2B). In the lagging strand, the primer fragments are generated by the activity of the gp61 primase which is recruited by gp41. At a later stage, the primers are removed by $\mathrm{RNaseH}$ and the gaps are sealed by the gp30 ligase $[6,29,32]$. With each subsequent cycle, the successive replication products 
would be shorter and shorter. The solution to this problem is the presence of a replication mechanism by recombination [33].

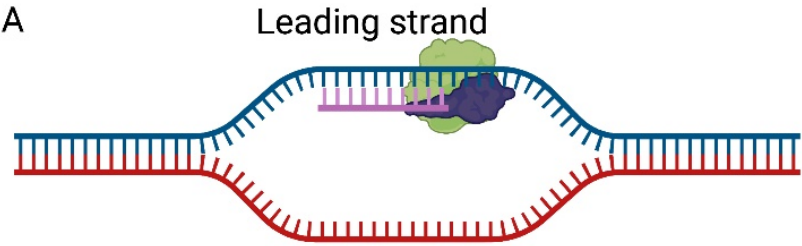

B
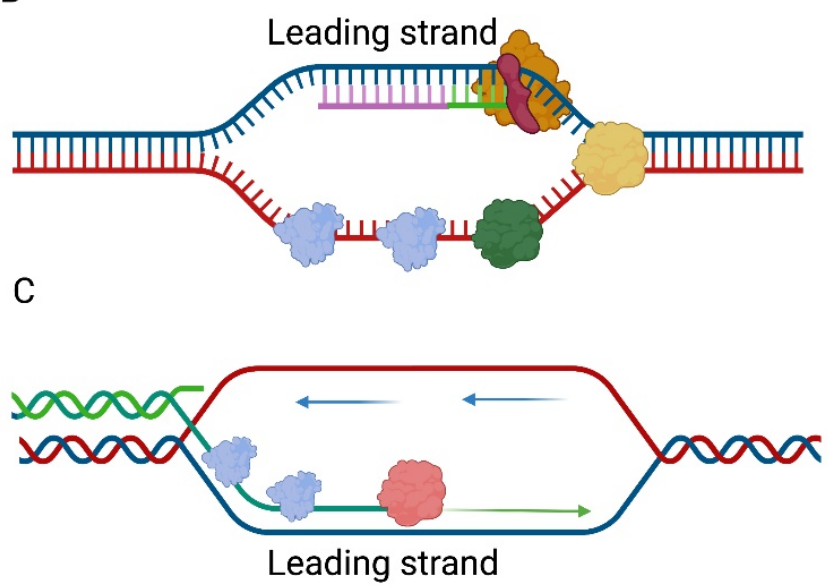

Figure 2. Replication of the bacteriophage T4 genome. (A) Origin of replication sites are recognized by host RNA polymerase (green) after replacement of the $\sigma^{70}$ subunit with bacteriophage-encoded AsiA $\sigma$-factor (blue). (B) The DNA polymerase gp43 (orange) needs sliding clamp gp45 (red) for replication of DNA. The unfolding of the double-stranded construct is ensured by the gp41 helicase (yellow). In the lagging strand, the primer fragments are generated by the activity of the gp61 primase (green) which is recruited by gp41 (yellow). The ssDNA structures are covered with gp32 SSB protein (blue). (C) After removal of RNA primers, the $3^{\prime}$-overhangs of lagging strand are covered with gp32 SSB (blue) and UvsX single-strand annealing protein (pink). Such a $3^{\prime}$-overhangs (green) can serve as a template for DNA polymerase by attaching to the homologous strand of another DNA molecule (blue and red). This creates a Y structure with a D loop, while the lagging strand is synthesized from Okazaki fragments that create subsequent molecules with $3^{\prime}$-overhangs.

Recombination-dependent replication of the bacteriophage T4 genome can follow five pathways. It depends on different conditions [34]. First, pathway I may occur when T4 DNA polymerase is inactivated by mutation. After infecting bacteria by T4 bacteriophage DNA, recombinational intermediates appear when dsDNA is fragmented and partially degraded by exonucleases and endonucleases. Second, in the absence of or impaired priming Okazaki fragments, late proteins endonuclease VII or terminase cut the invaded DNA providing primers for DNA polymerase in pathway III. Third, pathway IV is observed when T4 damaged DNA appears. It is called a double-strand-break repair (DSBR) recombination pathway. DNA synthesis is limited to repair DNA near the invasion sites and cutting occurs after formation of double-Holliday junctions. Fourth, in pathway $\mathrm{V}$ bubble-migration and ss-DNA annealing occur. It has been proposed to explain that asymmetries in gene conversion at intron homing sites occur because enzyme endonuclease VII is not required [34].

Pathway II is thought to play a major role in the replication of genetic material. The $3^{\prime}$-overhangs of lagging strands formed in this way are covered with gp32 SSB and UvsX single-strand annealing protein [35]. Such $3^{\prime}$-overhangs can serve as a template for DNA polymerase by attaching to the homologous strand of another DNA molecule (Figure 2C). This creates a Y structure with a D loop, while the lagging strand is synthesized from Okazaki fragments that create subsequent molecules with $3^{\prime}$-overhangs. For this reason, 
this type of DNA replication is called self-perpetuating. The end products of the reaction, i.e., the Holliday structures, are solved by gp49 endonuclease VII [34,36].

\subsection{DNA Replication of T7 Phage}

The replication of the T7 bacteriophage genome is mediated by a replication-bytranscription mechanism. Host RNA polymerase is responsible for the transcription of early genes, e.g., the gene encoding gp1 phage RNA polymerase [37]. The enzyme gp1 forms primers on the leading strands, which are then elongated by the DNA polymerase gp5 activity. Priming of the lagging strand is carried out by the bifunctional gp4 primasehelicase. Replication of the bacteriophage T7 genome is unidirectional for both strands, until the gp2.5 SSB initiates bi-directional DNA synthesis, resulting in the transformation of the replication "bubble" into a Y structure [7,38-40] (Figure 3A).

A Leading strand

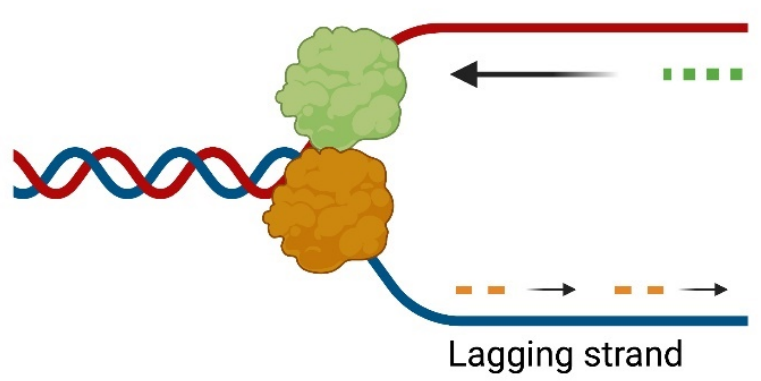

B
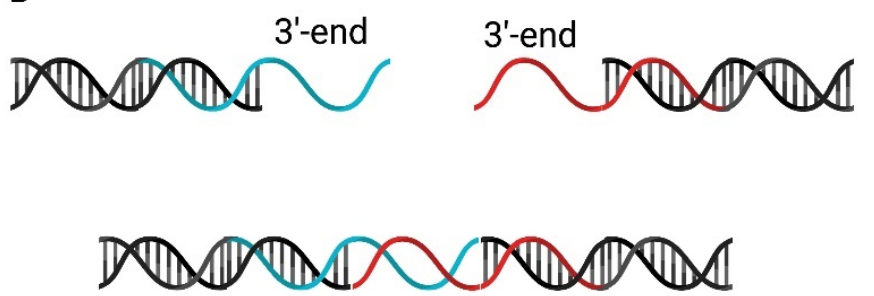

Figure 3. Replication of the bacteriophage T7 genome. (A) RNA polymerase, encoded by gene 1, recognizes the origins of replication and synthesizes the transcript (green dots). After initiation of bidirectional DNA synthesis by a 2.5 SSB gene product, the replication "bubble" transforms into a Y-structure. Priming (orange dots) of the lagging strand is carried out by the bifunctional protein primase-helicase (orange). (B) After removal of RNA primers, $3^{\prime}$-overhangs are formed which have repeats of about $160 \mathrm{bp}$ in length, allowing it to hybridize with itself to form concatemers.

Primers are removed by gp6 RNaseH activity, gap filling is performed by the production of gene 5 and gap sealing by gp1.3 DNA ligase [7]. The results of the action of the above-mentioned enzymes are ssDNA 3 '-overhangs. They have repeats of about $160 \mathrm{bp}$ in length, allowing them to hybridize with themselves to form concatemers, which are then assembled through ligase activity (Figure 3B). During successive rounds of DNA replication, Holliday structures are formed, which are resolved by the activity of endonuclease I, encoded by gene 3 . Subsequently, single-stranded $5^{\prime}$-overhangs are formed during concatemeric DNA packaging. The ends are filled in by DNA polymerase and exonuclease (gene 6 product), preventing strand-displacement synthesis $[41,42]$.

\section{Unusual Functions and Features of Recently Discovered Phage-Encoded DNA Polymerases}

Below we present several recently described examples of bacteriophage-encoded DNA polymerases that display unusual, noncanonical activities and/or interesting structural features. 


\subsection{Unexpected Translesion Synthesis by B-Family Phage Polymerase from Bam35 Phage}

Replicative DNA polymerases must synthesize DNA with high fidelity. That is why most of them have evolved to promote the proper base pairing; besides, the 'proofreading' $3^{\prime} \rightarrow 5^{\prime}$ exonuclease activity of the A- and B-family polymerases additionally assures the correctness of the nascent DNA strand [43]. The cost of such an adaptation is the fact that replicative DNA polymerases cannot pass through the DNA damage, resulting in stalled replication forks and replisome disassembly $[43,44]$. Damage-encountering replicative polymerases are exchanged with translesion synthesis (TLS) polymerases belonging to the polymerase family Y. Due to the specific structural features of their active center, TLS polymerases are able to bypass DNA lesion, but they are highly error-prone and exhibit low processivity [45].

In context of phage DNA replication, high fidelity and processivity have to be balanced with damage tolerance. This problem is especially relevant in cases of temperate bacteriophages because they can accumulate DNA lesions when integrated into the host genome during the lysogenic cycle. After prophage induction, phage DNA polymerase must deal with accumulated damage during phage DNA amplification. The most frequent kind of DNA lesions occurring in bacteria are abasic (apurinic/apyrimidinic) sites caused by the spontaneous or enzymatic hydrolysis of the N-glycosidic bond between the nitrogenous base and deoxyribose sugar [46] (Figure 4A).

A

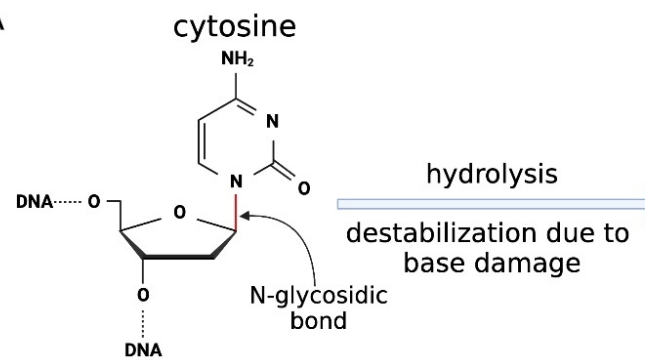

abasic (AP) site

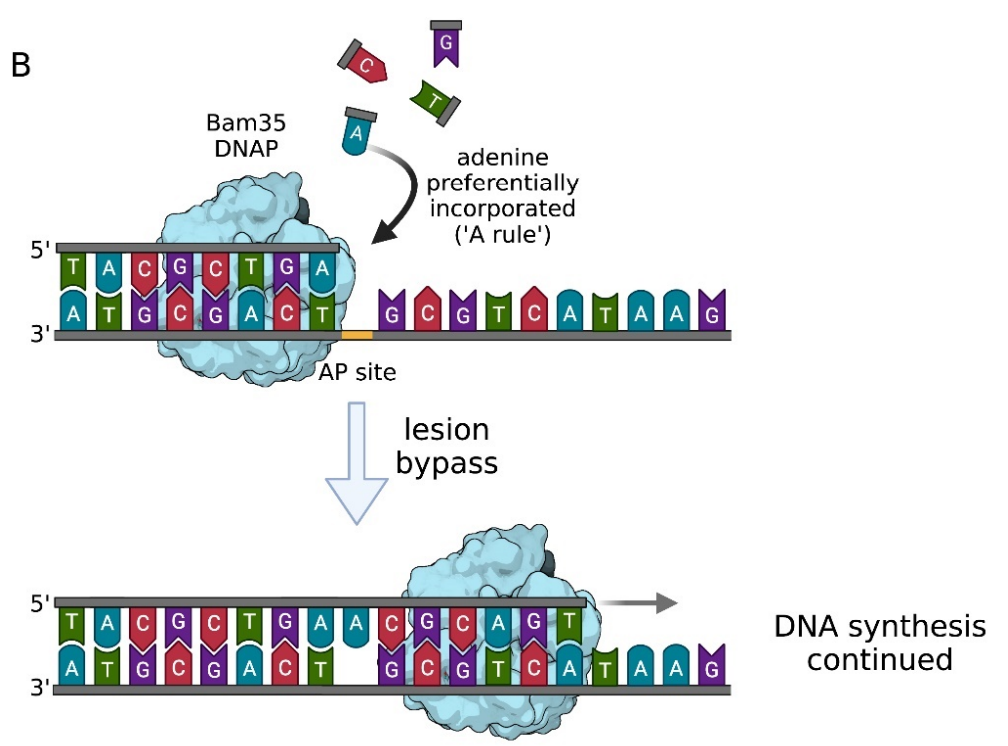

Figure 4. Abasic site bypass via the A-rule and translesion synthesis by Bam35 DNA polymerase. (A) Abasic AP sites form after the cleavage of the $\mathrm{N}$-glycosidic bond between nitrogenous base and deoxyribose sugar, whereas the phosphodiester backbone of DNA remains intact. Base loss may occur due to spontaneous or enzymatic hydrolysis as well as base damage leading to destabilization of N-glycosidic bond (adapted from [46], with modifications). (B) Translesion synthesis by Bam35 DNA polymerase. Once encountering an abasic site, Bam35DNAP (light blue) incorporates dATP opposite the lesion, passes through it and continues DNA synthesis in a faithful manner [47]. 
A phage-encoded DNA polymerase of Bacillus thuringiensis phage Bam 35 that has a surprising ability to bypass over abasic sites during DNA replication has been described [47]. It belongs to family B and shares structural (over $40 \%$ ) and functional similarity with $\$ 29$ DNA polymerase, along with the protein-priming mechanism. Biochemical assays in vitro showed that Bam35 polymerase exhibits efficient polymerase activity and $3^{\prime} \rightarrow 5^{\prime}$ exonuclease activity. Moreover, contrary to $\$ 29$ DNA polymerase, wild type Bam 35 proteins are able to insert a nucleotide opposite the abasic side as well as the first nucleotide beyond it, carrying on with DNA synthesis downstream of the lesion [47]. According to the so-called 'A-rule' used by TLS DNA polymerases [48], Bam35 polymerase preferentially incorporates dATP opposite the abasic site of DNA [47] (Figure 4B).

Protein-primed DNA polymerases contain two additional structural regions compared to the other B-family DNA polymerases. The first of them, named TPR1 (terminal protein region 1) is involved in interactions with primer terminal protein, second-TPR2-is responsible for strand displacement coupled to DNA synthesis and provides high enzyme processivity $[49,50]$. It has been revealed that Bam 35 DNA polymerase devoid of TPR2 still can insert nucleotides opposite the abasic site but loses the bypass ability and further DNA extension. It suggests that the TPR2 subdomain in Bam35 DNA polymerase may be involved in proficient TLS activity [47].

Bam35 DNA polymerase is a unique example of fully functional replicative enzyme with additional TLS activity. The balance of damage tolerance and faithful DNA synthesis within the single protein has an application potential in the fields where amplification of damaged DNA is needed, such as criminology or paleontology [47].

\subsection{Self-Priming Activity of Unique Hexameric Ring-Shaped DNA Polymerase from the NrS-1 Phage}

It has been commonly thought for years that DNA polymerases cannot synthesize DNA de novo and require the presence of a primer attached to the $5^{\prime}$-end of the template. Thus, replicative DNA polymerases need the assistance of primases, specific enzymes able to synthesize short RNA fragments at specific sequences on the DNA template, that can be subsequently extended [43]. However, the discovery of the so-called primase-polymerases (prim-pols) that have a role in replicating whole plasmid sequences in archaea was proof that de novo synthesis of long DNA fragment from dNTPs is also possible [51]. Prim-pols are sometimes classified as another DNA polymerase family [52]. In fact though, members of primer-independent family B polymerases, dubbed pipolBs, encoded by self-replicating mobile genetic elements in bacterial and mitochondrial DNA, have also been identified [53].

Recently, DNA polymerase from NrS-1 bacteriophage, responsible for the replication of its genome, shed a new light on de novo DNA synthesis. NrS-1 temperate bacteriophage was described in 2013 as a first isolated phage infecting the deep-sea vent Epsilonproteobacteria [54]. Interestingly, despite the presence of genes coding for helicase and ss-DNA binding protein, suggesting that replication of NrS-1 phage relies on its own enzymes, NrS-1 does not encode any replicative polymerase homologous to the known ones. However, it does have a gene with a small sequence homology to the DNA prim-pols identified on archaeal plasmids. It turned out that this gene indeed encodes replicative DNA polymerase that can both extend primed DNA strands and synthesize DNA de novo. The N-terminal part of the enzyme contains prim/pol domain with homologies to archaeal prim-pols and helix bundle domain (Figure 5). The N-terminal polymerase fragment of 300 residues is responsible for the DNA polymerization depending on divalent metal ion mechanism, based solely on template strands and dNTPs $[55,56]$. Notably, helix bundle domain is necessary for the priming activity, because the $\mathrm{N}$-terminal part of Nrs-1 polymerase containing only the first 200 residues was not able to synthesize DNA without a primer [55].

Typical primases as well as DNA prim-pols recognize their initiation site upon the 3-4 nucleotide sequence on DNA templates thanks to a zinc-binding motif in their structure [57]. In contrast, NrS-1 DNA polymerase lacks such a motif and recognizes longer, 
8-nucleotide sequences via Y261 residue, which implicates that the priming mechanism is different than in already described DNA prim-pols [55,56].

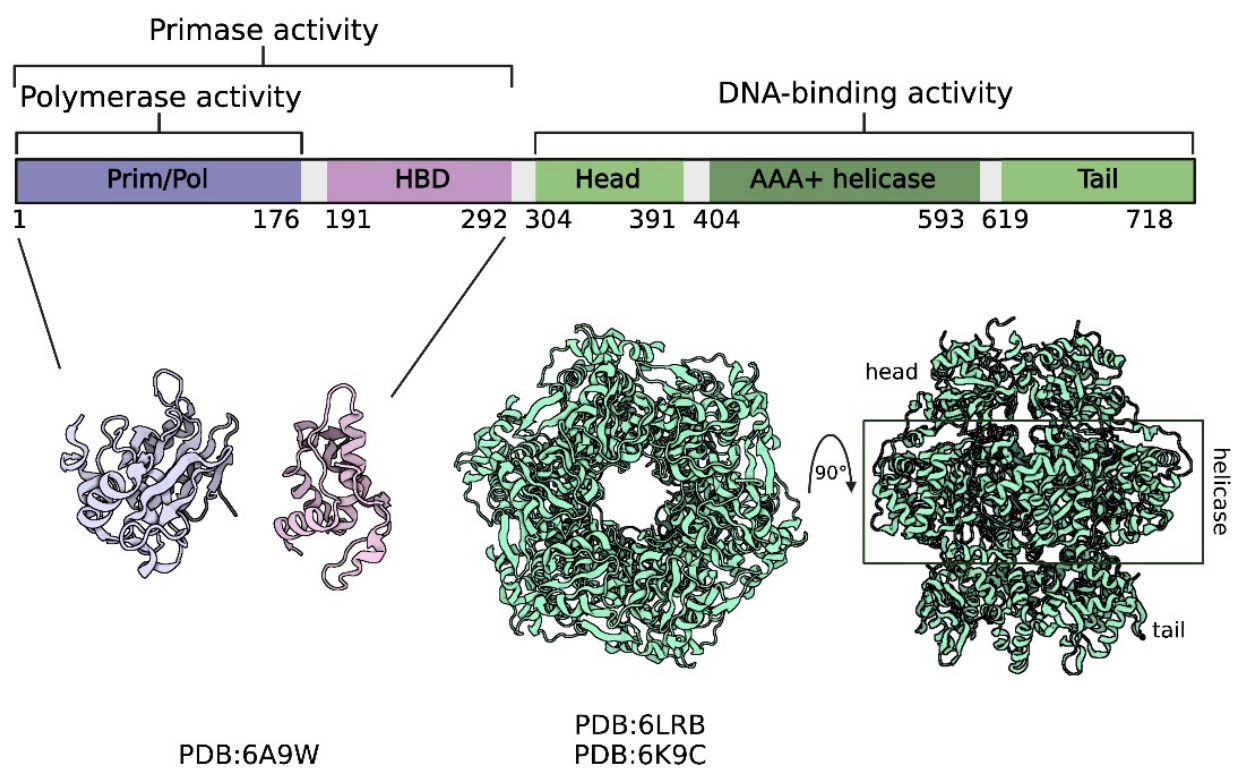

Figure 5. The scheme of functional domains in the NrS-1 DNA polymerase. The N-terminal part of the protein contains prim/pol domain and helix bundle domain (HBD), whereas the C-terminal region forms a hexameric ring consisting of AAA+ helicase domains and previously unknown head and tail regions (adapted from [58], with modifications).

The C-terminal part of the NrS-1 polymerase that proved to play important role in DNA binding and improving DNA polymerization efficiency has even more interesting features. Crystal structure resolution revealed that it forms a unique hexameric ring whose central region shares structural similarities with an AAA+ helicase domain, whereas head and tail residue structures have not been described before [58] (Figure 5). The C-terminal region possesses nucleotide hydrolysis and helicase activities. The latter is directly involved in enhancing the processivity of NrS-1 polymerase [58]. Electron microscopy analysis of the full-length protein revealed that the whole NrS-1 polymerase also adapts hexameric conformation unique among other DNA polymerases. Such unusual structure and function may play a role in proper replisome assembly and initiation of DNA replication during phage life cycle [58]. NrS-1 polymerase is a first example of phage main replicative enzyme with primer synthesis, DNA polymerization, and helicase activities.

\subsection{Incorporation of Non-Canonical Nucleotides by DNA Polymerases from 2-Aminoadenine Based Phages}

The DNA of all living organisms is composed of only four different nitrogenous bases: purines adenine $(A)$, guanine $(G)$, pyrimidines cytosine $(C)$, and thymine $(T)$. According to the canonical Watson-Crick rules, adenine pairs with thymine, and guanine with cytosine, forming two and three hydrogen bonds, respectively [59]. Bacteriophages, however, often use modified DNA bases to avoid recognition and degradation of their genetic material by host defense systems, i.e., restriction endonucleases. One of the flagship examples of such mechanisms is the presence of 5-hydroxymethylcytosine instead of cytosine in T-even phages, such as T2, T4, and T6 (other types of base modifications present in bacteriophage DNA and their functions are reviewed in [60]).

Recently published articles focused on especially interesting modifications of bacterial DNA in terms of DNA polymerization. Several bacteriophages that belong to the Siphoviridae and Podoviridae families, including Vibrio phage $\phi \mathrm{VC} 8$ or Synechococcus phage S-2L, are entirely devoid of adenine, which is replaced in their genome by 2 -aminoadenine $(2,6-$ diaminopurine, Z) [61]. Unlike an A-T pair, Z-T forms three hydrogen bonds contravening 
the Watson-Crick rules of base pairing [59] (Figure 6A). Genome features of S-2L phage have been already known for over 30 years [62], but the problem of its replication seems to be neglected.

S-2L and other bacteriophages whose genomes are built of aminoadenine nucleotides (referred below as 'aminoadenine phages') encode PurZ-an enzyme involved in the first step of dZTP synthesis from dGMP [63]. Pezo and coworkers wondered whether there exists a polymerase that specifically incorporates dZTP into DNA. After a database search, they revealed that all aminoadenine phages, except S-2L, contain a gene homolog of polA from E. coli, which they called $d p o Z$ [64]. DpoZ enzymes from four different phages, overproduced in E. coli and purified to homogeneity, functionally resemble the Klenow fragment of family A DNA polymerase I, but show significantly higher affinity to dZTP over dATP [64]. The crystal structure of the apo form of DpoZ from vibriophage $\phi V C 8$ showed that this polymerase is structurally quite a typical member of the A family [65]. It consists of a polymerase domain with palm, thumb, and fingers subdomains as well as a $3^{\prime} \rightarrow 5^{\prime}$ exonuclease domain. Compared to E. coli Pol I, $\phi$ VC8 DpoZ has three small sequence insertions that form external loops in the palm and fingers domains. However, neither single structural motif nor specific residue(s) in the polymerase domain that could justify the preference for dZTPs during DNA synthesis have been identified [65]. Therefore, substrate preference may arise from the combination of several structural features. The authors suggest that the possible mechanism of Z-vs-A specificity relates to the switching between polymerase and exonuclease activity during DNA synthesis. It was recently shown that in response to replication obstacles, DNA polymerase backtracks the nascent DNA strand and sends it to the exonuclease domain, where even a correctly incorporated nucleotide is excised [66] (Figure 6B). According to Czernecki and coworkers, backtracking activity of DpoZ enzyme could be especially high and somehow sensitive to the strength of the nascent base pair, that is to the number of forming hydrogen bonds, in favor of aminoadenine [65] (Figure 6C). Structural basics of this mechanism remain yet to be elucidated.

Since an S-2L phage has no dpoZ gene homolog, the question is how it can incorporate $\mathrm{Z}$ over $\mathrm{A}$ into the DNA. It turned out that $\mathrm{S}-2 \mathrm{~L}$ contains a gene encoding protein of the prim-pol type that seems to be its only replicative polymerase. Subsequent structural and functional analyses revealed that the S-2L DNA polymerase folds similarly to archaeal prim-pols and-surprisingly-shows no discrimination of A against $Z$ [67]. The reason for dZTP usage in S-2L phage lies in the presence of products of two other genes, DatZ-triphosphohydrolase specific of dATP and MazZ-(d)GTP-specific diphosphohydrolase $[67,68]$. The former degrades dATP to remove the alternative for dZTP and the latter hydrolyzes dGTP to dGMP providing substrate for (and therefore ensuring a high rate of) dZTP synthesis by PurZ. DatZ and MazZ homologs are also found in phages encoding the DpoZ polymerase [68].

Taken together, the 'molecular ostracism' of adenine and exclusive incorporation of dZTP into DNA result from several activities of enzymes encoded by aminoadenine phages' genomes, at different stages of phage life cycle. At the pre-replicative stage, dATP is eliminated by the enzymatic degradation thanks to specific triphosphohydrolase while concomitantly dZTP synthesis is promoted by providing high amounts of dGMP. At replicative stage, in turn, using dZTP as a DNA building block is supported by newly described features of DpoZ DNA polymerase [64,65,67]. 
A<smiles>Cc1cn(C)c(=O)[nH]c1=O</smiles>

adenine : thymine

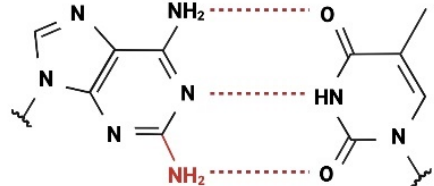

2-aminoadenine : thymine

B

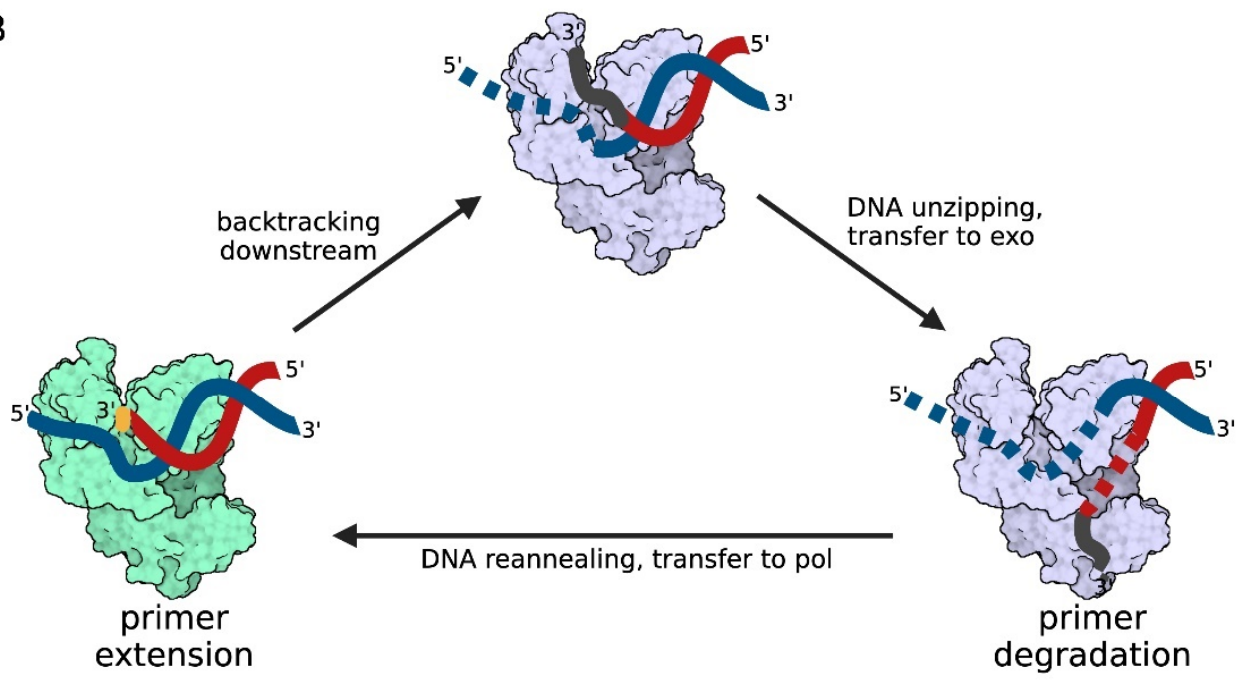

C
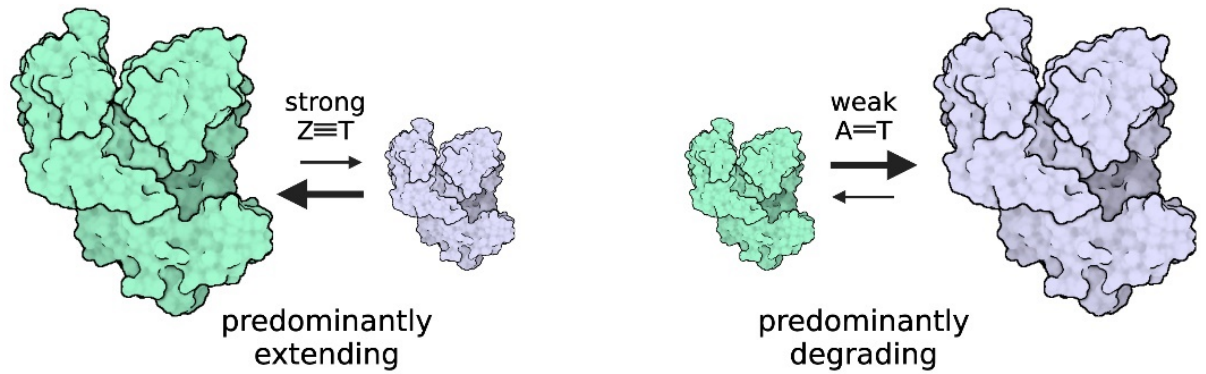

Figure 6. The Z-vs-A specificity of DpoZ polymerase from aminoadenine phages. (A) Structural formulas of adenine:thymine and 2-aminoadenine:thymine base pairs. (B) Mechanism of DNA polymerase backtracking and switching between polymerase and exonuclease activities. During DNA synthesis (polymerase in green), the template (blue) and primer (red) strains are tightly placed in the enzyme's active center. The primer is extended at $3^{\prime}$-end (pale orange). However, the nascent strand (grey fragment) is occasionally backtracked and in consequence DNA is uncoupled and single strand fragments become disordered (dotted lines). As a result, the primer strand is sent to the exonuclease site (polymerase in light purple), where 2-3 terminal nucleotides are subsequently removed before switching to the extending mode (adapted from [65]). (C) DpoZ specificity may relate to high backtracking activity dependent on the number of formed hydrogen bonds. When dATP (two bonds with thymine) appears in the active site, DpoZ polymerase backtracks the nascent strand and transfers it to the exonuclease site where adenine is removed. In contrast, dZTP (three bonds with thymine) allows for the polymerase to stay predominantly in the extending mode (adapted from [65]).

\section{Bacteriophage-Encoded DNA Polymerases as a Powerful Application Tool in Biotechnology}

There are few DNA polymerases encoded by bacteriophages that have found applications in biotechnology. This is not due to a lack of applications in this field, but rather 
to limited knowledge about them. However, ongoing research makes it possible to learn more and more about the newly discovered enzymes encoded by these viruses. The most known enzymes that are used in genetic engineering are DNA polymerases encoded by bacteriophages $\varphi 29$, T4 and T7.

Several applications of DNA polymerases of T4 and T7 phages can be found in the literature. Due to their similar activities $\left(5^{\prime}\right.$ to $3^{\prime}$ polymerase activity, $3^{\prime}$ to $5^{\prime}$ exonuclease activity) and properties, they also have similar fields of application. Both can be effectively used in filling $5^{\prime}$-overhangs or removing $3^{\prime}$-overhangs [69]. Another common application is DNA strand elongation during site-specific mutagenesis [70,71]. However, despite these similarities, the aforementioned DNA polymerases obviously differ in applications. The DNA polymerase encoded by phage T4 can be used during the synthesis of labelled DNA by replacement reaction and in cloning independent of ligation of PCR products [72]. In contrast, phage T7 DNA polymerase is used to remove residual genomic DNA during circular DNA purification. A major advantage of T7 DNA polymerase is the efficient elongation of templates with a large number of base pairs. It is also used to synthesize complementary cDNA strands [73]. Another use is the possibility of labelling the $3^{\prime}$ ends of DNA [73]. An interesting application is its use for the in situ detection of fragmented DNA as a result of apoptosis, thanks to its ability to label niches present in double-stranded DNA [74].

Among all bacteriophage-encoded DNA polymerases, $\varphi 29$ DNA polymerase $(\varphi 29$ DNAP) has significantly widespread application potential for several reasons. Apart from the protein-priming mechanism described before, $\varphi 29$ DNAP also accepts DNAor RNA-primers. Its high fidelity due to $3^{\prime}$ to $5^{\prime}$ proofreading activity and extremely high processivity accompanied with strand displacement activity [75] makes it a useful enzyme for various isothermal DNA amplification methods. The most popular ones where $\varphi 29$ DNAP is used are rolling circle amplification [76] and multiple displacement amplification [77], which is now commonly used for the whole genome amplification [78]. Moreover, it has been recently shown that $\varphi 29$ DNAP exhibits limited reverse transcriptase activity that enables it to replicate circular, RNA-containing templates, and thus broadens the application opportunities [79]. The construction of chimeric $\varphi 29$ DNAP with enhanced DNA binding due to the fusion with helix-hairpin-helix domains [80] and in vitro evolution of $\varphi 29$ DNAP performed to date [81] clearly show that this enzyme is quite engineeringprone and even further improving of its activity is possible.

The DNA polymerase of phage $\varphi 29$ has also found its application in DNA sequencing. For instance, it has been successfully used in single molecule real-time sequencing where immobilized DNA polymerase incorporates labelled nucleotides that are fluorescently detected [82,83]. An especially interesting example of $\varphi 29$ DNAP application is nanopore sequencing. In this technique, a pore protein is inserted into a membrane separating two salt solutions. When a voltage is applied across the membrane, a nascent DNA strand synthesized by polymerase is passed through the pore and this DNA movement causes the sequence-dependent change of ionic current. Manrao and coworkers combined modified Mycobacterium smegmatis porin A protein MspA with highly processive $\varphi 29$ DNAP. While synthesizing DNA, $\varphi 29$ DNAP functions as a motor that pulls single-stranded DNA through the MspA protein and detects current changes that clearly correspond to the known DNA sequences [84]. The same system turned out to be effective to detect unnatural bases in DNA, such as dNaM and d5SICS. Here, $\varphi 29$ DNA polymerase is flexible enough to unzip DNA strands containing unnatural bases and move them through the MspA where base-specific current levels can be detected [85].

Unexpectedly high flexibility of $\varphi 29$ DNAP allows for the use of this enzyme for xenobiotic nucleic acids (XNAs) biosynthesis. XNAs are synthetic genetic polymers that have at least one chemical moiety (phosphate, sugar, or nucleobase) changed in comparison to their natural equivalents. The major advantage of XNAs over DNA or RNA is their higher chemical and biological stability, especially useful in the construction of novel nanostructures [86]. Natural DNA polymerases do not generally manage to accept backbone modifications in 
XNAs, and they require extensive engineering to cope with XNAs synthesis. However, it has been revealed that only one amino acid substitution impairing exonuclease activity in $\varphi 29$ DNAP makes this enzyme able to synthesize XNAs [87]. This polymerase has been shown to be an effective enzyme for the synthesis of 1,5-anhydrohexitol nucleic acid (HNA), $2^{\prime}$-deoxy-2'-fluoro-arabinonucleic acid (FANA), and $2^{\prime}$-fluoro-DNA, where the canonical ribofuranose ring is replaced with hexitol, fluoroarabinose, and $2^{\prime}$-fluoro- $2^{\prime}$-deoxyribose, respectively $[86,87]$. Because only a single mutation is sufficient to provide XNAs synthesis (whereas 14 substitutions have been required to obtain the same activity of archaeal DNA polymerase from Thermococcus gorgonarius [87]), highly processive $\varphi 29$ DNAP (and possibly other bacteriophage-encoded DNA polymerases) constitutes a significant perspective for further XNAs research and development of XNA-based biomaterials.

\section{Concluding Remarks}

Bacteriophages are the most numerous and widespread biological entities in the world [88]. They not only have adapted to the environment of their hosts but also developed numerous mechanisms to escape hosts' defense systems. That is why DNA polymerases encoded in phages' genomes may exhibit features and activities that have not been observed before.

Examples of recent discoveries presented in this article prove that phage-encoded DNA polymerases can show activities unusual for the members of the family they belong to [47], display unique, previously undescribed structures [58], or even disobey canonical rules of base pairing during DNA synthesis adopted by all living organisms [64].

Even in single habitat the biodiversity of bacteriophages is enormous [89]. However, the number of complete phage genome sequences deposited in genetic databases is relatively small (10,830 of complete phage genomes, in comparison to almost 364,000 bacterial genomes, deposited in GenBank, as accessed on 30 November 2021; https: / www.ncbi.nlm.nih.gov/ genome/browse/\#!/viruses/), especially when one considers their biological abundance. That is why newly isolated bacteriophages from environmental samples need to be extensively characterized in search of genes encoding unknown proteins or enzymes of unusual activities. For instance, the analysis of a group of bacteriophages isolated from urban sewage revealed that three of them possessed genes encoding for DNA polymerases [90,91]. DNA polymerase from Enterococcus faecalis-infecting bacteriophage vB_EfaS-271 is predicted to belong to family B [90], but it does not show high similarity to other members of this family. Therefore, studies on DNA polymerases from newly described bacteriophages would provide better understanding of their action during the phage life cycle, which could also be useful in terms of the potential application of phage polymerases in biotechnology.

Author Contributions: Conceptualization, J.M.-O., K.Z. and A.W.; writing-original draft preparation, J.M.-O., K.Z. and A.W.; writing - review and editing, J.M.-O., K.Z. and A.W.; visualization, J.M.-O.; supervision, A.W.; project administration, A.W.; funding acquisition, A.W. All authors have read and agreed to the published version of the manuscript.

Funding: This research was funded by Institute of Biochemistry and Biophysics of Polish Academy of Sciences (task grant no. PN-32).

Institutional Review Board Statement: Not applicable.

Informed Consent Statement: Not applicable.

Data Availability Statement: Not applicable.

Acknowledgments: The authors thank Michał Szymański and Grzegorz Węgrzyn for discussions and advices. All figures were created using BioRender.com (accessed on 29 November 2021).

Conflicts of Interest: The authors declare no conflict of interest. 


\section{References}

1. Kunkel, T.A.; Bebenek, K. DNA Replication Fidelity. Annu. Rev. Biochem. 2000, 69, 497-529. [CrossRef]

2. Filée, J.; Forterre, P.; Sen-Lin, T.; Laurent, J. Evolution of DNA polymerase families: Evidences for multiple gene exchange between cellular and viral proteins. J. Mol. Evol. 2002, 54, 763-773. [CrossRef]

3. Kelleher, C.; Teixeira, M.T.; Förstemann, K.; Lingner, J. Telomerase: Biochemical considerations for enzyme and substrate. Trends Biochem. Sci. 2002, 27, 572-579. [CrossRef]

4. Garcia-Diaz, M.; Bebenek, K. Multiple functions of DNA polymerases. CRC Crit. Rev. Plant Sci. 2007, 26, 105-122. [CrossRef]

5. Choi, K.H. Viral polymerases. Adv. Exp. Med. Biol. 2012, 726, 267-304. [CrossRef] [PubMed]

6. Miller, E.S.; Kutter, E.; Mosig, G.; Arisaka, F.; Kunisawa, T.; Rüger, W. Bacteriophage T4 Genome. Microbiol. Mol. Biol. Rev. 2003, 67, 86-156. [CrossRef]

7. Richardson, C.C. Bacteriophage T7: Minimal requirements for the replication of a duplex DNA molecule. Cell 1983, 33, 315-317. [CrossRef]

8. Méndez, J.; Blanco, L.; Salas, M. Protein-primed DNA replication: A transition between two modes of priming by a unique DNA polymerase. EMBO J. 1997, 16, 2519-2527. [CrossRef]

9. Karam, J.D.; Konigsberg, W.H. DNA polymerase of the T4-related bacteriophages. Prog. Nucleic Acid Res. Mol. Biol. 2000, 64. [CrossRef]

10. Joyce, C.M.; Steitz, T.A. Function and structure relationships in DNA polymerases. Annu. Rev. Biochem. 1994, 63, 777-822. [CrossRef]

11. Hubscher, U.; Spadari, S.; Villani, G.; Maga, G. DNA Polymerases Discovery, Characterization and Functions in Cellular DNA Transactions. Brenner's Encycl. Genet. Second Ed. 2013, 376-378. [CrossRef]

12. Alba, M.M. Replicative DNA polymerase. Genome Biol. 2001, 2, REVIEWS3002. [CrossRef] [PubMed]

13. Rothwell, P.J.; Waksman, G. Structure and mechanism of DNA polymerases. Adv. Protein Chem. 2005, 71, 401-440. [CrossRef]

14. Wang, J.; Sattar, A.K.M.A.; Wang, C.C.; Karam, J.D.; Konigsberg, W.H.; Steitz, T.A. Crystal structure of a pol $\alpha$ family replication DNA polymerase from bacteriophage RB69. Cell 1997, 89, 1087-1099. [CrossRef]

15. Hashimoto, H.; Nishioka, M.; Fujiwara, S.; Takagi, M.; Imanaka, T.; Inoue, T.; Kai, Y. Crystal structure of DNA polymerase from hyperthermophilic archaeon Pyrococcus kodakaraensis KOD1. J. Mol. Biol. 2001, 306, 469-477. [CrossRef]

16. Huang, Y.P.; Ito, J. DNA polymerase $\mathrm{C}$ of the thermophilic bacterium Thermus aquaticus: Classification and phylogenetic analysis of the family C DNA polymerases. J. Mol. Evol. 1999, 48, 756-769. [CrossRef] [PubMed]

17. Yamtich, J.; Sweasy, J.B. DNA polymerase Family X: Function, structure, and cellular roles. Biochim. Biophys. Acta-Proteins Proteom. 2010, 1804, 1136-1150. [CrossRef]

18. Boudsocq, F.; Kokoska, R.J.; Plosky, B.B.; Vaisman, A.; Ling, H.; Kunkel, T.A.; Yang, W.; Woodgate, R. Investigating the role of the little finger domain of Y-family DNA polymerases in low fidelity synthesis and translesion replication. J. Biol. Chem. 2004, 279, 32932-32940. [CrossRef]

19. Lehmann, A.R. New functions for Y family polymerases. Mol. Cell 2006, 24, 493-495. [CrossRef] [PubMed]

20. Doublié, S.; Ellenberger, T. The mechanism of action of T7 DNA polymerase. Curr. Opin. Struct. Biol. 1998, 8, 704-712. [CrossRef]

21. Bernad, A.; Zaballos, A.; Salas, M.; Blanco, L. Structural and functional relationships between prokaryotic and eukaryotic DNA polymerases. EMBO J. 1987, 6, 4219. [CrossRef] [PubMed]

22. Hermoso, J.M.; Freire, R.; Bravo, A.; Gutiérrez, C.; Serrano, M.; Salas, M. DNA structure in the nucleoprotein complex that activates replication of phage Ø/29. Biophys. Chem. 1994, 50, 183-189. [CrossRef]

23. Salas, M.; Martin, G.; Bernard, A.; Garmendia, C.; Lazaro, J.M.; Zaballos, A.; Serrano, M.; Otero, M.J.; Gutierrez, J.; Pares, E.; et al. Protein-primed replication of bacteriophage phi29. Biochim. Biophys. Acta 1988, 951, 419-424. [CrossRef]

24. Watabe, K.; Leusch, M.; Ito, J. Replication of bacteriophage $\varphi 29$ DNA in vitro: The roles of terminal protein and DNA polymerase. Proc. Natl. Acad. Sci. USA 1984, 81, 5374-5378. [CrossRef]

25. Salas, M.; Freire, R.; Soengas, M.S.; Esteban, J.A.; Méndez, J.; Bravo, A.; Serrano, M.; Blasco, M.A.; Lázaro, J.M.; Blanco, L.; et al. Protein-nucleic acid interactions in bacteriophage $\varphi 29$ DNA replication. FEMS Microbiol. Rev. 1995, 17, 73-82. [CrossRef]

26. Mendez, J.; Blanco, L.; Esteban, J.A.; Bernad, A.; Salas, M. Initiation of $\varphi 29$ DNA replication occurs at the second $3^{\prime}$ nucleotide of the linear template: A sliding-back mechanism for protein-primed DNA replication. Proc. Natl. Acad. Sci. USA 1992, 89, 9579-9583. [CrossRef] [PubMed]

27. Luder, A.; Mosig, G. Two alternative mechanisms for initiating of DNA replication forks in bacteriophage T4: Priming by RNA polymerase and by recombination. Proc. Natl. Acad. Sci. USA 1982, 79, 1101-1105. [CrossRef]

28. Dudas, K.C.; Kreuzer, K.N. UvsW Protein Regulates Bacteriophage T4 Origin-Dependent Replication by Unwinding R-Loops. Mol. Cell. Biol. 2001, 21, 2706-2715. [CrossRef]

29. Barry, J.; Alberts, B. Purification and characterization of bacteriophage T4 gene 59 protein. A DNA helicase assembly protein involved in DNA replication. J. Biol. Chem. 1994, 269, 33049-33062. [CrossRef]

30. Venkatesan, M.; Silver, L.L.; Nossal, N.G. Bacteriophage T4 gene 41 protein, required for the synthesis of RNA primers, is also a DNA helicase. J. Biol. Chem. 1982, 257, 12426-12434. [CrossRef]

31. Jones, C.E.; Mueser, T.C.; Nossal, N.G. Interaction of the Bacteriophage T4 Gene 59 Helicase Loading Protein and Gene 41 Helicase with Each Other and with Fork, Flap, and Cruciform DNA. J. Biol. Chem. 2000, 275, 27145-27154. [CrossRef] 
32. Benkovic, S.J.; Valentine, A.M.; Salinas, F. Replisome-mediated DNA replication. Annu. Rev. Biochem. 2001, 70, 181-208. [CrossRef] [PubMed]

33. Formosa, T.; Alberts, B.M. DNA synthesis dependent on genetic recombination: Characterization of a reaction catalyzed by purified bacteriophage T4 proteins. Cell 1986, 47, 793-806. [CrossRef]

34. Mosig, G. Recombination and recombination-dependent DNA replication in bacteriophage T4. Annu. Rev. Genet. 1998, 32, 379-413. [CrossRef] [PubMed]

35. Bleuit, J.S.; Ma, Y.; Munro, J.; Morrical, S.W. Mutations in a Conserved Motif Inhibit Single-stranded DNA Binding and Recombination Mediator Activities of Bacteriophage T4 UvsY Protein. J. Biol. Chem. 2004, 279, 6077-6086. [CrossRef]

36. Kreuzer, K.N. Recombination-dependent DNA replication in phage T4. Trends Biochem. Sci. 2000, 25, 165-173. [CrossRef]

37. Hinkle, D.C. Evidence for direct involvement of T7 RNA polymerase bacteriophage DNA replication. J. Virol. 1980, 34, 136-141. [CrossRef]

38. Dressler, D.; Wolfson, J.; Magazin, M. Initiation and reinitiation of DNA synthesis during replication of bacteriophage T7. Proc. Natl. Acad. Sci. USA 1972, 69, 998-1002. [CrossRef]

39. Saito, H.; Tabor, S.; Tamanoi, F.; Richardson, C.C. Nucleotide sequence of the primary origin of bacteriophage T7 DNA replication: Relationship to adjacent genes and regulatory elements. Proc. Natl. Acad. Sci. USA 1980, 77, 3917-3921. [CrossRef]

40. Fuller, C.W.; Richardson, C.C. Initiation of DNA replication at the primary origin of bacteriophage T7 by purified proteins. Initiation of bidirectional synthesis. J. Biol. Chem. 1985, 260, 3197-3206. [CrossRef]

41. Watson, J.D. Origin of Concatemeric T7 DNA. Nature 1972, 239, 137-138. [CrossRef]

42. Sugimoto, K.; Miyasaka, T.; Fujiyama, A.; Kohara, Y.; Okazaki, T. Change in priming sites for discontinuous DNA synthesis between the monomeric and concatemeric stages of phage T7 replication. MGG Mol. Gen. Genet. 1988, 211, 400-406. [CrossRef]

43. Johansson, E.; Dixon, N. Replicative DNA polymerases. Cold Spring Harb. Perspect. Biol. 2013, 5, a012799. [CrossRef]

44. Branzei, D.; Foiani, M. Maintaining genome stability at the replication fork. Nat. Rev. Mol. Cell Biol. 2010, 11, 208-219. [CrossRef] [PubMed]

45. Yang, W. An Overview of Y-Family DNA Polymerases anda Case Study of Human DNA Polymerase $\eta$. Biochemistry 2014, 53, 2793. [CrossRef] [PubMed]

46. Thompson, P.S.; Cortez, D. New Insights into Abasic Site Repair and Tolerance. DNA Repair 2020, 90, 102866. [CrossRef] [PubMed]

47. Berjón-Otero, M.; Villar, L.; De Vega, M.; Salas, M.; Redrejo-Rodríguez, M. DNA polymerase from temperate phage Bam35 is endowed with processive polymerization and abasic sites translesion synthesis capacity. Proc. Natl. Acad. Sci. USA 2015, 112, E3476-E3484. [CrossRef] [PubMed]

48. Strauss, B.S. The "A" rule revisited: Polymerases as determinants of mutational specificity. DNA Repair 2002, 1, 125-135. [CrossRef]

49. Dufour, E.; Méndez, J.; Lázaro, J.M.; De Vega, M.; Blanco, L.; Salas, M. An aspartic acid residue in TPR-1, a specific region of protein-priming DNA polymerases, is required for the functional interaction with primer terminal protein. J. Mol. Biol. 2000, 304, 289-300. [CrossRef]

50. Rodríguez, I.; Lázaro, J.M.; Blanco, L.; Kamtekar, S.; Berman, A.J.; Wang, J.; Steitz, T.A.; Salas, M.; De Vega, M. A specific subdomain in phi29 DNA polymerase confers both processivity and strand-displacement capacity. Proc. Natl. Acad. Sci. USA 2005, 102, 6407-6412. [CrossRef]

51. Lipps, G.; Weinzierl, A.O.; Von Scheven, G.; Buchen, C.; Cramer, P. Structure of a bifunctional DNA primase-polymerase. Nat. Struct. Mol. Biol. 2004, 11, 157-162. [CrossRef] [PubMed]

52. Guilliam, T.A.; Keen, B.A.; Brissett, N.C.; Doherty, A.J. Primase-polymerases are a functionally diverse superfamily of replication and repair enzymes. Nucleic Acids Res. 2015, 43, 6651-6664. [CrossRef] [PubMed]

53. Redrejo-Rodríguez, M.; Ordóñez, C.D.; Berjón-Otero, M.; Moreno-González, J.; Aparicio-Maldonado, C.; Forterre, P.; Salas, M.; Krupovic, M. Primer-Independent DNA Synthesis by a Family B DNA Polymerase from Self-Replicating Mobile Genetic Elements. Cell Rep. 2017, 21, 1574. [CrossRef]

54. Yoshida-Takashima, Y.; Takaki, Y.; Shimamura, S.; Nunoura, T.; Takai, K. Genome sequence of a novel deep-sea vent epsilonproteobacterial phage provides new insight into the co-evolution of Epsilonproteobacteria and their phages. Extremophiles 2013, 17, 405-419. [CrossRef] [PubMed]

55. Zhu, B.; Wang, L.; Mitsunobu, H.; Lu, X.; Hernandez, A.J.; Yoshida-Takashima, Y.; Nunoura, T.; Tabor, S.; Richardson, C.C Deep-sea vent phage DNA polymerase specifically initiates DNA synthesis in the absence of primers. Proc. Natl. Acad. Sci. USA 2017, 114, E2310-E2318. [CrossRef] [PubMed]

56. Guo, H.; Li, M.; Wang, T.; Wu, H.; Zhou, H.; Xu, C.; Yu, F.; Liu, X.; He, J. Crystal structure and biochemical studies of the bifunctional DNA primase-polymerase from phage NrS-1. Biochem. Biophys. Res. Commun. 2019, 510, 573-579. [CrossRef] [PubMed]

57. Frick, D.N.; Richardson, C.C. DNA primases. Annu. Rev. Biochem. 2001, 70, 39-80. [CrossRef]

58. Chen, X.; Su, S.; Chen, Y.; Gao, Y.; Li, Y.; Shao, Z.; Zhang, Y.; Shao, Q.; Liu, H.; Li, J.; et al. Structural studies reveal a ring-shaped architecture of deep-sea vent phage NrS-1 polymerase. Nucleic Acids Res. 2020, 48, 3343-3355. [CrossRef] [PubMed]

59. Watson, J.D.; Crick, F.H.C. Genetical Implications of the Structure of Deoxyribonucleic Acid. Nature 1953, 171, 964-967. [CrossRef] [PubMed] 
60. Weigele, P.; Raleigh, E.A. Biosynthesis and Function of Modified Bases in Bacteria and Their Viruses. Chem. Rev. 2016, 116, 12655-12687. [CrossRef] [PubMed]

61. Zhou, Y.; Xu, X.; Wei, Y.; Cheng, Y.; Guo, Y.; Khudyakov, I.; Liu, F.; He, P.; Song, Z.; Li, Z.; et al. A widespread pathway for substitution of adenine by diaminopurine in phage genomes. Science 2021, 372, 512-516. [CrossRef]

62. Kirnos, M.D.; Khudyakov, I.Y.; Alexandrushkina, N.I.; Vanyushin, B.F. 2-Aminoadenine is an adenine substituting for a base in S-2L cyanophage DNA. Nature 1977, 270, 369-370. [CrossRef]

63. Sleiman, D.; Garcia, P.S.; Lagune, M.; Loc'h, J.; Haouz, A.; Taib, N.; Röthlisberger, P.; Gribaldo, S.; Marlière, P.; Kaminski, P.A. A third purine biosynthetic pathway encoded by aminoadenine-based viral DNA genomes. Science 2021, 372, 516-520. [CrossRef]

64. Pezo, V.; Jaziri, F.; Bourguignon, P.Y.; Louis, D.; Jacobs-Sera, D.; Rozenski, J.; Pochet, S.; Herdewijn, P.; Hatfull, G.F.; Kaminski, P.A.; et al. Noncanonical DNA polymerization by aminoadenine-based siphoviruses. Science 2021, 372, 520-524. [CrossRef]

65. Czernecki, D.; Hu, H.; Romoli, F.; Delarue, M. Structural dynamics and determinants of 2-aminoadenine specificity in DNA polymerase DpoZ of vibriophage $\phi \mathrm{VC}$. Nucleic Acids Res. 2021, 49, 11974-11985. [CrossRef]

66. Singh, A.; Pandey, M.; Nandakumar, D.; Raney, K.D.; Yin, Y.W.; Patel, S.S. Excessive excision of correct nucleotides during DNA synthesis explained by replication hurdles. EMBO J. 2020, 39, e103367. [CrossRef]

67. Czernecki, D.; Legrand, P.; Tekpinar, M.; Rosario, S.; Kaminski, P.; Delarue, M. How cyanophage S-2L rejects adenine and incorporates 2-aminoadenine to saturate hydrogen bonding in its DNA. Nat. Commun. 2021, 12, 2420. [CrossRef] [PubMed]

68. Czernecki, D.; Bonhomme, F.; Kaminski, P.; Delarue, M. Characterization of a triad of genes in cyanophage S-2L sufficient to replace adenine by 2-aminoadenine in bacterial DNA. Nat. Commun. 2021, 12, 4710. [CrossRef] [PubMed]

69. Bodescot, M.; Brison, O. T7 DNA Polymerase Requires Unusual Reaction Conditions for Blunt-Ending Activity. Anal. Biochem. 1994, 216, 234-235. [CrossRef] [PubMed]

70. Kunkel, T.A. Rapid and efficient site-specific mutagenesis without phenotypic selection. Proc. Natl. Acad. Sci. USA 1984, 31, 54-58. [CrossRef]

71. Bebenek, K.; Kunkel, T.A. The use of native T7 DNA polymerase for site-directed mutagenesis. Nucleic Acids Res. 1989, 17, 5408. [CrossRef] [PubMed]

72. Du, R.; Li, S.; Zhang, X. A modified plasmid vector pCMV-3Tag-LIC for rapid, reliable, ligation-independent cloning of polymerase chain reaction products. Anal. Biochem. 2011, 408, 357-359. [CrossRef] [PubMed]

73. Bodescot, M.; Brison, O. Efficient Second-Strand cDNA Synthesis Using T7 DNA Polymerase. DNA Cell Biol. 1994, 65, 39-42. [CrossRef]

74. Wood, K.A.; Dipasquale, B.; Youle, R.J. In situ labeling of granule cells for apoptosis-associated DNA fragmentation reveals different mechanisms of cell loss in developing cerebellum. Neuron 1993, 11, 621-632. [CrossRef]

75. Berman, A.J.; Kamtekar, S.; Goodman, J.L.; Lázaro, J.M.; De Vega, M.; Blanco, L.; Salas, M.; Steitz, T.A. Structures of phi29 DNA polymerase complexed with substrate: The mechanism of translocation in B-family polymerases. EMBO J. 2007, 26, 3494-3505. [CrossRef] [PubMed]

76. Dean, F.B.; Nelson, J.R.; Giesler, T.L.; Lasken, R.S. Rapid amplification of plasmid and phage DNA using Phi 29 DNA polymerase and multiply-primed rolling circle amplification. Genome Res. 2001, 11, 1095-1099. [CrossRef]

77. Dean, F.B.; Hosono, S.; Fang, L.; Wu, X.; Faruqi, A.F.; Bray-Ward, P.; Sun, Z.; Zong, Q.; Du, Y.; Du, J.; et al. Comprehensive human genome amplification using multiple displacement amplification. Proc. Natl. Acad. Sci. USA 2002, 99, 5261-5266. [CrossRef] [PubMed]

78. Kroneis, T.; El-Heliebi, A. Whole Genome Amplification by Isothermal Multiple Strand Displacement Using Phi29 DNA Polymerase. Methods Mol. Biol. 2015, 1347, 111-117. [CrossRef]

79. Krzywkowski, T.; Kühnemund, M.; Wu, D.; Nilsson, M. Limited reverse transcriptase activity of phi29 DNA polymerase. Nucleic Acids Res. 2018, 46, 3625-3632. [CrossRef]

80. De Vega, M.; Lázaro, J.M.; Mencía, M.; Blanco, L.; Salas, M. Improvement of $\varphi 29$ DNA polymerase amplification performance by fusion of DNA binding motifs. Proc. Natl. Acad. Sci. USA 2010, 107, 16506-16511. [CrossRef]

81. Sakatani, Y.; Mizuuchi, R.; Ichihashi, N. In vitro evolution of phi29 DNA polymerases through compartmentalized gene expression and rolling-circle replication. Protein Eng. Des. Sel. 2019, 32, 481-487. [CrossRef]

82. Korlach, J.; Marks, P.J.; Cicero, R.L.; Gray, J.J.; Murphy, D.L.; Roitman, D.B.; Pham, T.T.; Otto, G.A.; Foquet, M.; Turner, S.W. Selective aluminum passivation for targeted immobilization of single DNA polymerase molecules in zero-mode waveguide nanostructures. Proc. Natl. Acad. Sci. USA 2008, 105, 1176. [CrossRef] [PubMed]

83. Ardui, S.; Ameur, A.; Vermeesch, J.R.; Hestand, M.S. Single molecule real-time (SMRT) sequencing comes of age: Applications and utilities for medical diagnostics. Nucleic Acids Res. 2018, 46, 2159. [CrossRef]

84. Manrao, E.A.; Derrington, I.M.; Laszlo, A.H.; Langford, K.W.; Hopper, M.K.; Gillgren, N.; Pavlenok, M.; Niederweis, M.; Gundlach, J.H. Reading DNA at single-nucleotide resolution with a mutant MspA nanopore and phi29 DNA polymerase. Nat. Biotechnol. 2012, 30, 349-353. [CrossRef]

85. Craig, J.M.; Laszlo, A.H.; Derrington, I.M.; Ross, B.C.; Brinkerhoff, H.; Nova, I.C.; Doering, K.; Tickman, B.I.; Svet, M.T.; Gundlach, J.H. Direct Detection of Unnatural DNA Nucleotides dNaM and d5SICS using the MspA Nanopore. PLoS ONE 2015, 10, e143253. [CrossRef] 
86. Pinheiro, V.B.; Holliger, P. Towards XNA nanotechnology: New materials from synthetic genetic polymers. Trends Biotechnol. 2014, 32, 321-328. [CrossRef]

87. Torres, L.L.; Pinheiro, V.B. Xenobiotic Nucleic Acid (XNA) Synthesis by Phi29 DNA Polymerase. Curr. Protoc. Chem. Biol. 2018, 10, e41. [CrossRef] [PubMed]

88. Comeau, A.M.; Hatfull, G.F.; Krisch, H.M.; Lindell, D.; Mann, N.H.; Prangishvili, D. Exploring the prokaryotic virosphere. Res. Microbiol. 2008, 159, 306-313. [CrossRef] [PubMed]

89. Jurczak-Kurek, A.; Gasior, T.; Nejman-Faleńczyk, B.; Bloch, S.; Dydecka, A.; Topka, G.; Necel, A.; Jakubowska-Deredas, M.; Narajczyk, M.; Richert, M.; et al. Biodiversity of bacteriophages: Morphological and biological properties of a large group of phages isolated from urban sewage. Sci. Rep. 2016, 6, 34338. [CrossRef] [PubMed]

90. Topka-Bielecka, G.; Bloch, S.; Nejman-Faleńczyk, B.; Grabski, M.; Jurczak-Kurek, A.; Górniak, M.; Dydecka, A.; Necel, A.; Weegrzyn, G.; Węgrzyn, A. Characterization of the Bacteriophage vB_EfaS-271 Infecting Enterococcus faecalis. Int. J. Mol. Sci. 2020, 21, 6345. [CrossRef] [PubMed]

91. Kosznik-Kwaśnicka, K.; Ciemińska, K.; Grabski, M.; Grabowski, Ł.; Górniak, M.; Jurczak-Kurek, A.; Wegrzyn, G.; Wegrzyn, A. Characteristics of a Series of Three Bacteriophages Infecting Salmonella enterica Strains. Int. J. Mol. Sci. 2020, 21, 6152. [CrossRef] [PubMed] 